\title{
Modelowanie numeryczne ładunków kumulacyjnych z wkładkami dzielonymi dwuczęściowymi
}

\section{Numerical modelling of shaped charges with divided two-piece liners}

\author{
Kamil Hebda ${ }^{1}$, Łukasz Habera, ${ }^{1}$ Piotr Koślik ${ }^{2}$ \\ ${ }^{1}$ Instytut Nafty i Gazu - Państwowy Instytut Badawczy \\ ${ }^{2}$ Sieć Badawcza Łukasiewicz - Instytut Przemysłu Organicznego, Oddział w Krupskim Młynie
}

\begin{abstract}
STRESZCZENIE: Niniejszy artykuł powstał na podstawie wyników modelowania numerycznego ładunków kumulacyjnych z nietypowym kształtem wkładki kumulacyjnej. Standardowy ładunek typu deep penetrating (głęboko penetrujący) posiada wkładkę kumulacyjną w kształcie stożka wykonaną z miedzi. Zamodelowano trzy geometrie ładunków kumulacyjnych o niekonwencjonalnym kształcie, które porównano do modelu klasycznego ładunku. Ładunki te porównano pod względem maksymalnego ciśnienia podczas detonacji, prędkości strumienia kumulacyjnego, uzyskanej energii kinetycznej oraz długości strumienia kumulacyjnego po czasie $22 \mu$ s. Celem modelowania ładunków kumulacyjnych z wkładkami o niekonwencjonalnym kształcie było sprawdzenie, czy są one w stanie poprawić parametry zabiegu perforacji w odwiertach naftowych. Perforacja otworu naftowego to krytyczny zabieg, dzięki któremu możliwe jest rozpoczęcie wydobycia węglowodorów z danego złoża. Zabieg ten polega na wykonaniu serii kanałów prostopadłych do osi otworu penetrujących ścianki rur okładzinowych, cementu oraz skałę złożową w celu utworzenia połączenia hydraulicznego pomiędzy otworem wiertniczym a złożem węglowodorów. W przemyśle naftowym ładunki typu deep penetrating są projektowane, aby zapewnić optymalną długość kanału perforacyjnego przy zachowaniu odpowiedniej średnicy perforacji. Obecnie najpowszechniej używanymi ładunkami kumulacyjnymi głęboko penetrującymi są ładunki osiowosymetryczne z wkładkami kumulacyjnymi w kształcie stożka wykonanymi z proszków miedzi. Ładunki te osiągają prędkość strumienia kumulacyjnego na poziomie $7000 \mathrm{~m} / \mathrm{s}$ i w sprzyjających warunkach są w stanie spenetrować do $1 \mathrm{~m}$ calizny skalnej. W artykule opisano parametry ładunków kumulacyjnych, które uzyskano w wyniku modelowania numerycznego. W celu potwierdzenia zdolności przebijania celów przez zamodelowane ładunki należałoby sprawdzić ich fizyczne modele w warunkach poligonu doświadczalnego.
\end{abstract}

Słowa kluczowe: perforacja, ładunki kumulacyjne, niekonwencjonalny kształt wkładki, modelowanie numeryczne.

ABSTRACT: The article was created on the grounds of numerical modelling of shaped charges with a focus on the unconventional shape of their liners. The standard shaped charge of the "deep penetrating" type is equipped with a conical liner made of copper. Three various geometries of shaped charges featuring unconventional shape have been modelled and compared with the classical model of a shaped charge. The shaped charges have been compared for maximum pressure during detonation, cumulative jet velocity, kinetic energy gained and length of cumulative jet after $22 \mu \mathrm{s}$. The purpose of modelling shaped charges, featuring unconventionally formed liners, was to check whether they are able to improve the perforation job parameters in oil and gas wells. Perforation of the borehole is a critical job, enabling the initiation of hydrocarbons production from a specific reservoir. The job consists in making series of channels perpendicular to the borehole axis, penetrating casing walls, the cement layer and the formation rock, in order to create a hydraulic link between the borehole and the reservoir of hydrocarbons. In the oil industry, the "deep penetrating" type shaped charges are designed in order to provide optimal length of the perforation channel, while maintaining its adequate perforating diameter. Nowadays, the most commonly deep-penetrating shaped charges used, are the axially-symmetric shaped charges with conical liners made of copper powders. The charges create a cumulative jet reaching a velocity of approx. $7000 \mathrm{~m} / \mathrm{sec}$ and are able to penetrate up to $1 \mathrm{~m}$ of rock matrix in favourable conditions. The article describes the parameters of shaped charges, that have been obtained as a result of numerical modelling. In order to finally confirm the target penetrating ability by the modelled shaped charges, one should check their real physical models in fire-ground conditions.

Key words: perforation, shaped charges, unconventional shape of liner, numerical modeling.

Autor do korespondencji: K. Hebda, e-mail: kamil.hebda@inig.pl

Artykuł nadesłano do Redakcji: 12.01.2021 r. Zatwierdzono do druku: 08.04.2021 r. 


\section{Wstęp}

W artykule Hebdy i Habery (2020) zamodelowano ładunki kumulacyjne z eliptycznymi wkładkami. Ładunek kumulacyjny skupia miejscowo efekt działania detonacji (Frodyma i Koślik, 2016). Współczesne ładunki składają się z wkładki kumulacyjnej w postaci stożka. Wkładka znajduje się w centrum liniowego ładunku kumulacyjnego. Deformacja wkładki kumulacyjnej pod siłą detonacji ładunku wybuchowego jest krytycznym działaniem podczas tworzenia strumienia kumulacyjnego. Początkowo wkładki kumulacyjne były produkowane $\mathrm{z}$ litego metalu. Konstrukcje te $\mathrm{z}$ powodzeniem produkowały strumienie kumulacyjne o wysokiej gęstości, ale miały tendencję do łączenia tuneli perforacyjnych. Nowoczesne konstrukcje wkładek oparte są na sproszkowanych metalach, które zapewniają wystarczającą gęstość strumienia do głębokiej penetracji bez niepożądanych skutków ubocznych, takich jak zatykanie się formacji. Obecnie najczęściej stosowanym metalem do produkcji wkładek jest miedź. Wkładka kumulacyjna jest podścielona materiałem wybuchowym. Najczęściej są to heksogen (RDX) oraz oktogen (HMX) - materiały wybuchowe o wysokiej prędkości i ciśnieniu detonacji. Materiały te nigdy nie są w czystej postaci, ponieważ są zbyt wrażliwe. Dodatkowo materiał wybuchowy musi być jednorodny oraz równomiernie rozdystrybuowany w celu głębszej penetracji danego ośrodka (Schlumberger, 1993; Zygmunt et al., 2014; Elbeih et al., 2020; IPO, 2020). Całość ładunku zamyka się w obudowie, zazwyczaj wykonanej ze stali, cynku, aluminium, rzadziej z innych materiałów, takich jak ceramika czy szkło. Ostatnim elementem w ładunku kumulacyjnym jest zapalnik, który zapewnia połączenie pomiędzy lontem detonującym a ładunkiem. Ładunki kumulacyjne są wykorzystywane zarówno w zastosowaniach militarnych, cywilnych, jak też w górnictwie, np. perforacja w otworach wiertniczych przy eksploracji węglowodorów (Schlumberger, 1993; Elbeih et al., 2020).

Ważnym narzędziem przy projektowaniu ładunków kumulacyjnych jest modelowanie komputerowe, które może symulować proces detonacji ładunku o dowolnym kształcie w pamięci komputera, bez konieczności budowania prototypu (Banaś, 2020).

Modelowanie układów wykonuje się np. z wykorzystaniem metody elementów skończonych (MES), opierającej się na rozwiązywaniu układów równań różniczkowych z podziałem na skończone elementy, dla których rozwiązanie jest przybliżane przez konkretne funkcje, i przeprowadzaniu obliczeń tylko dla węzłów tego podziału (Balonek i Gozdur, 1999).

Zjawisko kumulacji należy do szybkozmiennych oddziaływań dynamicznych. Zachowanie się materiałów podczas symulacji opisują odpowiednie modele. Podstawowym modelem symulacji dla metali w warunkach silnych obciążeń dynamicznych jest model ciała sprężysto-lepko-plastycznego. Model matematyczno-fizyczny zjawiska opisany jest równaniami dotyczącymi ośrodków ciągłych: prawem zachowania, modelem konstruktywnym Johnsona-Cooka lub Steinberga-Guinana, równaniami stanu dla ciał stałych oraz modelem hydrodynamicznym dla produktów detonacji stałego materiału wybuchowego. Dodatkowo metody, za pomocą których możemy modelować dane zjawiska, to: metoda Lagrange'a, metoda Eulera, metody lagrange'owsko-eulerowskie, metoda wygładzonej hydrodynamiki cząstek, metoda elementów skończonych, metoda punktów swobodnych (Wojewódka et al., 2010).

Wykorzystując metodę MES, można zasymulować detonację ładunku kumulacyjnego wraz z jego najważniejszymi parametrami, takimi jak: ciśnienie maksymalne w układzie, prędkość strumienia kumulacyjnego oraz z wytworzoną przez ładunek energią kinetyczną. Przy modelowaniu można dowolnie zmieniać kształt i parametry ładunku kumulacyjnego, np. grubość wkładki, jej kształt, materiał, z którego została wykonana, oraz dobrać materiał wybuchowy (Cheng et al., 2018).

\section{Materiały}

Modelowanie procesu formowania się strumieni kumulacyjnych przeprowadzono przy zastosowaniu specjalistycznego oprogramowania komputerowego, wykorzystując program Ansys z modułami LS-dyna oraz Autodyn.

Przeprowadzono analizę dla czterech modeli ładunków kumulacyjnych:

- klasycznego ładunku z wkładką stożkową wykonaną z miedzi;

- ładunku z wkładką dzieloną dwuczęściową I;

- ładunku z wkładką dzieloną dwuczęściową I oraz soczewką;

- ładunku z wkładką dzieloną dwuczęściową II.

Do modelowania wszystkich ładunków przyjęto następujące stałe materiałowe:

- obudowa wykonana ze stali;

- wkładka wykonana z miedzi o średnicy podstawy wynoszącej 34,7 mm;

- materiał wybuchowy RDX flegmatyzowany.

Budowę układu zrealizowano w postaci jednej ćwiartki bryły przestrzennej osiowosymetrycznej (3D). Model ładunku umieszczono w przestrzeni walcowej wypełnionej powietrzem o średnicy $70 \mathrm{~mm}$ i wysokości $135 \mathrm{~mm}$. Założono możliwość obserwowania formującego się strumienia i jego części czołowej na dystansie do 2 kalibrów - 69,4 mm (kaliber to średnica podstawy wkładki kumulacyjnej), licząc od podstawy ładunku / wkładki kumulacyjnej. Ponadto przyjęto uproszczenia modelowe niemające wpływu na prawidłowe funkcjonowanie modelu i wyniki analizy (uproszczenia geometrii obudowy - fazowania krawędzi i punktowe inicjowanie detonacji). 


\section{NAFTA-GAZ}

Prezentowane analizy numeryczne ładunków kumulacyjnych zakładają wykorzystanie obudów stalowych, przeznaczonych do perforatorów typu PRS 114 (typ obudowy jak dla ładunku ŁOKT-Fe-33-150 opracowanego przez Zakład Techniki Strzelniczej Instytutu Nafty i Gazu - Państwowego Instytutu Badawczego).

\section{Standardowy tadunek kumulacyjny z wktadka stożkowa}

Budowa wkładki hybrydowej tego typu polega na montażu dwóch odrębnych wkładek (A i B) poprzez precyzyjne (współosiowe) złożenie. Istnieje możliwość ich zespolenia za pomocą cienkiej warstwy kleju (rys. 1 i 2).

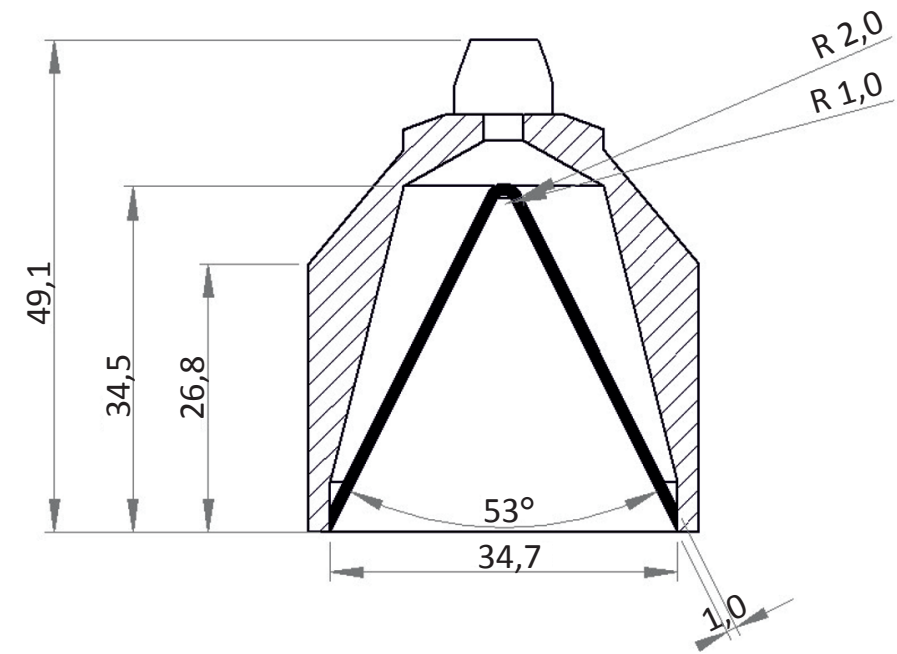

Rys. 1. Przekrój przez klasyczny ładunek kumulacyjny z wkładką stożkową wykonaną z miedzi

Fig. 1. Sectional view of a traditional shaped charge with a conical liner made of copper

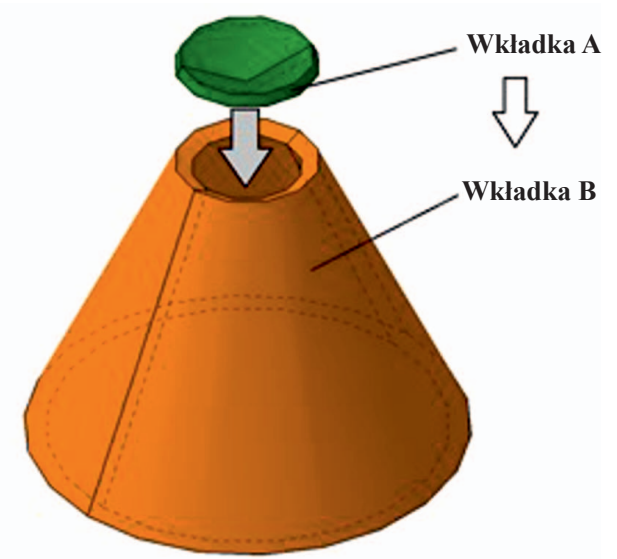

Rys. 2. Schemat złożenia wkładki dwuczęściowej

Fig. 2. Assembly diagram of a two-piece liner

\section{Hybrydowy ladunek kumulacyjny z wkladka dzielona dwuczęściowa I}

Przy projektowaniu tej wkładki wykorzystano stożkowy element złożenia skierowany w stronę zagłębienia kumulacyjnego (rys. 3).

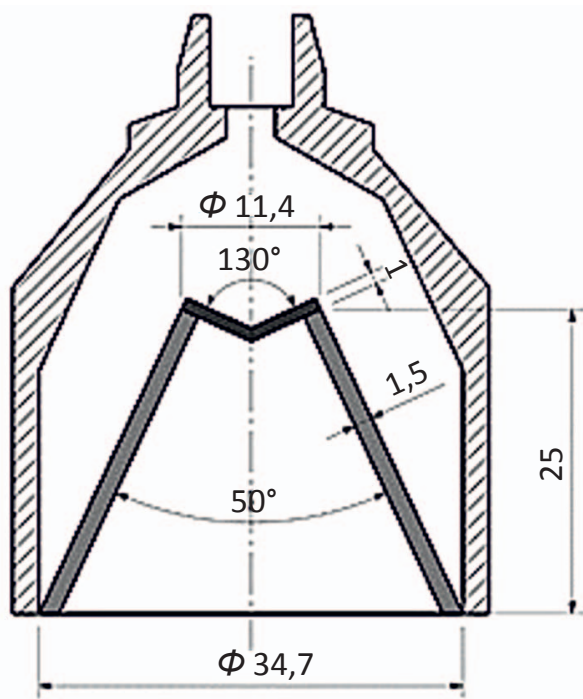

Rys. 3. Przekrój przez ładunek kumulacyjny z wkładką dzieloną dwuczęściową I

Fig. 3. Sectional view of a shaped charge with a two-piece split liner I

\section{Hybrydowy tadunek kumulacyjny z wktadka dzielonq dwuczęściowa I oraz soczewka}

Budowa ładunku jest taka sama jak w przypadku poprzedniego modelu $-\mathrm{z}$ dodatkowym elementem $\mathrm{w}$ postaci soczewki wykonanej z teflonu, która ma za zadanie poprawić parametry strumienia kumulacyjnego (rys. 4).

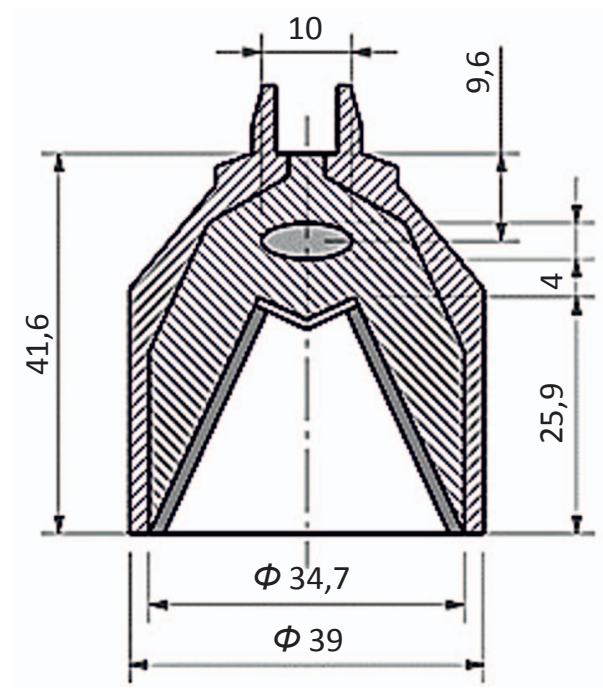

Rys. 4. Przekrój przez ładunek kumulacyjny z wkładką dzieloną dwuczęściową I oraz soczewką

Fig. 4. Sectional view of a shaped charge with a two-piece split liner I and lens

\section{Hybrydowy tadunek kumulacyjny z, wktadka dzielona dwuczęściowa II}

Przy projektowaniu tej wkładki wykorzystano płaski kształt elementu złożenia (rys. 5). 


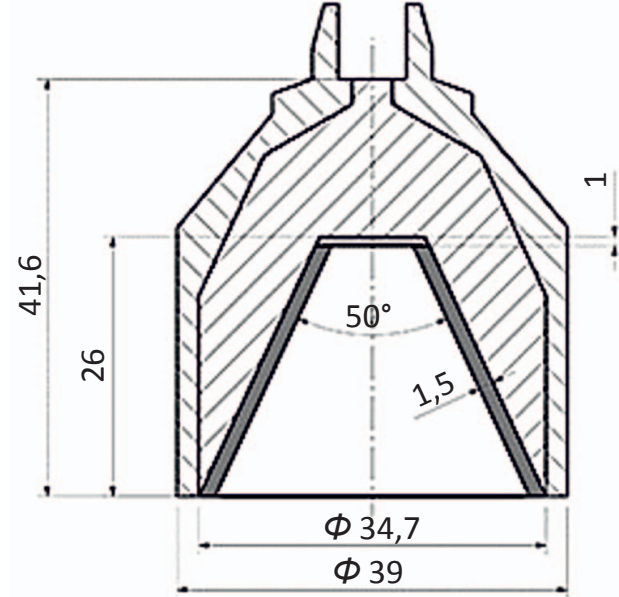

Rys. 5. Przekrój przez ładunek kumulacyjny z wkładką dzieloną dwuczęściową II

Fig. 5. Sectional view of a shaped charge with a two-piece split liner II

\section{Wyniki}

W wyniku modelowania otrzymano wartości, które zestawiono w tabeli 1.

Analizując dane zawarte w tabeli 1, zaobserwowano, że zamodelowane ładunki kumulacyjne $\mathrm{z}$ wkładkami hybrydowymi nieco później detonują oraz osiągnęły wyraźnie gorsze parametry maksymalnej zarejestrowanej prędkości strumienia kumulacyjnego w porównaniu do klasycznego ładunku kumulacyjnego. Czas detonacji jest o $0,05 \mu$ s późniejszy. Maksymalna prędkość ustabilizowanego strumienia kumulacyjnego (po $52 \mathrm{~mm}$ od podstawy ładunku) dla klasycznego ładunku kumulacyjnego wynosi $5900 \mathrm{~m} / \mathrm{s}$, zamodelowane ładunki hybrydowe uzyskały tę wartość na poziomie od $5250 \mathrm{~m} / \mathrm{s}$ do $5564 \mathrm{~m} / \mathrm{s}$. Hybrydowe ładunki kumulacyjne osiągnęły lepsze parametry maksymalnej wartości ciśnienia strumienia kumulacyjnego oraz wartości energii kinetycznej wkładki (łącznie strumienia i zbitka) od klasycznego ładunku kumulacyjnego. Największe ciśnienie uzyskał ładunek z wkładką dzieloną dwuczęściową I oraz soczewką - na poziomie $39 \mathrm{GPa}$, kolejno ładunek z wkładką dzieloną dwuczęściową II - na poziomie $37 \mathrm{GPa}$; ładunek z wkładką dzieloną dwuczęściową I osiągnął ciśnienie maksymalne na poziomie $35 \mathrm{GPa}$ i jest to wartość nieco niższa od uzyskanej przez klasyczny ładunek kumulacyjny z wkładką stożkową - 35,7 GPa. Największe wartości energii kinetycznej osiągnął ładunek kumulacyjny z wkładką dzieloną dwuczęściową II - na poziomie $31,2 \mathrm{~kJ}$, kolejno ładunki kumulacyjne $\mathrm{z}$ wkładką dzieloną dwuczęściową I oraz z wkładką dzieloną dwuczęściową I i soczewką - na poziomie $29,8 \mathrm{~kJ}$; jest to więcej od standardowego ładunku kumulacyjnego, który wygenerował 23,3 kJ energii kinetycznej wkładki.

Na rysunku 6 zestawiono ze sobą długości poszczególnych zamodelowanych strumieni kumulacyjnych po czasie $22 \mu \mathrm{s}$.

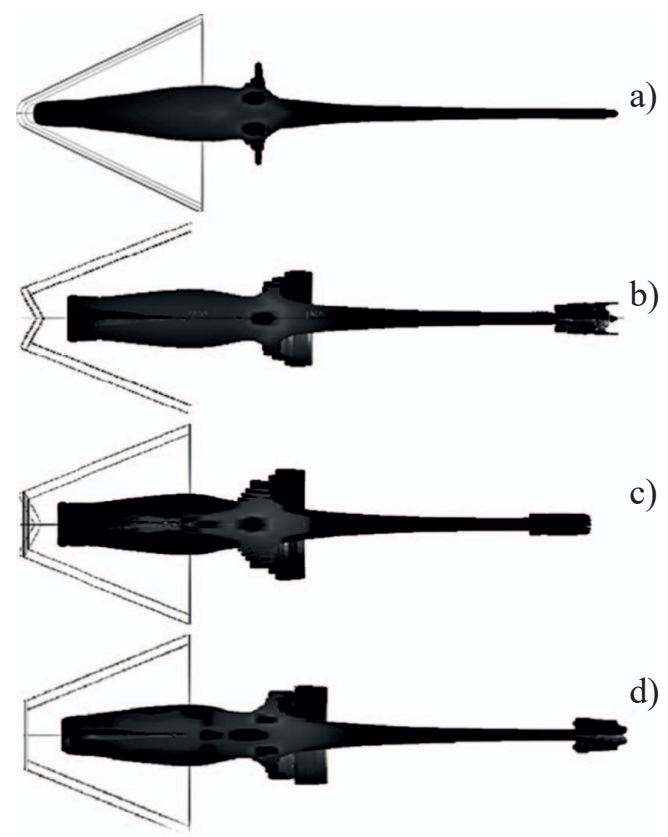

Rys. 6. Zestawione ze sobą strumienie kumulacyjne po czasie $22 \mu \mathrm{s}$ dla zamodelowanych ładunków kumulacyjnych: a) klasyczny ładunek kumulacyjny z wkładką stożkową wykonaną z miedzi, b) ładunek kumulacyjny z wkładką dzieloną dwuczęściową I, c) ładunek kumulacyjny z wkładką dzieloną dwuczęściową I oraz soczewką i d) ładunek kumulacyjny z wkładką dzieloną dwuczęściową II

Fig. 6. Compared ranges of cumulative jets after a time of $22 \mu \mathrm{s}$ for modelled shaped charges: a) traditional shaped charge with a conical liner made of copper, b) shaped charge with a two-piece split liner I, c) shaped charge with a two-piece split liner I and lens and d) shaped charge with a two-piece split liner II

Tabela 1. Zestawienie najważniejszych parametrów uzyskanych podczas modelowania ładunków kumulacyjnych

Table 1. List of most important parameters obtained during modelling of shaped charges

\begin{tabular}{|c|c|c|c|c|}
\hline \multirow[t]{2}{*}{ Ladunek } & $\begin{array}{l}\text { Detonacja } \\
\text { ladunku }\end{array}$ & $\begin{array}{c}\text { Ustabilizowana } \\
\text { prędkość strumienia }\end{array}$ & $\begin{array}{c}\text { Maksymalne } \\
\text { zarejestrowane ciśnienie } \\
\text { strumienia }\end{array}$ & $\begin{array}{c}\text { Energia } \\
\text { kinetyczna } \\
\text { wkladki }\end{array}$ \\
\hline & {$[\mu s]$} & {$[\mathrm{m} / \mathbf{s}]$} & [GPa] & {$[\mathbf{k J}]$} \\
\hline Kumulacyjny z wkładką stożkową & 4,8 & 5900 & 35,7 & 23,3 \\
\hline Kumulacyjny z wkładką dzieloną dwuczęściową I & 4,85 & 5250 & 35 & 29,8 \\
\hline $\begin{array}{l}\text { Kumulacyjny z wkładką dzieloną dwuczęściową I } \\
\text { oraz soczewką }\end{array}$ & 4,85 & 5564 & 39 & 29,8 \\
\hline Kumulacyjny z wkładką dzieloną dwuczęściową II & 4,85 & 5460 & 37 & 31,2 \\
\hline
\end{tabular}


Porównując strumienie kumulacyjne po czasie $22 \mu \mathrm{s}$, zaobserwowano, że ładunki mają zbliżoną do siebie długość. Główna różnica pomiędzy standardowym ładunkiem kumulacyjnym a ładunkami hybrydowymi wynika z kształtu czoła strumienia kumulacyjnego. Strumień w klasycznym ładunku kumulacyjnym z wkładką stożkową jest stosunkowo jednorodny. Ładunki hybrydowe w czole strumienia posiadają zgrubienie.

Poniżej przedstawiono proces formowania się strumienia kumulacyjnego w hybrydowym ładunku kumulacyjnym z wkładką dzieloną dwuczęściową I.

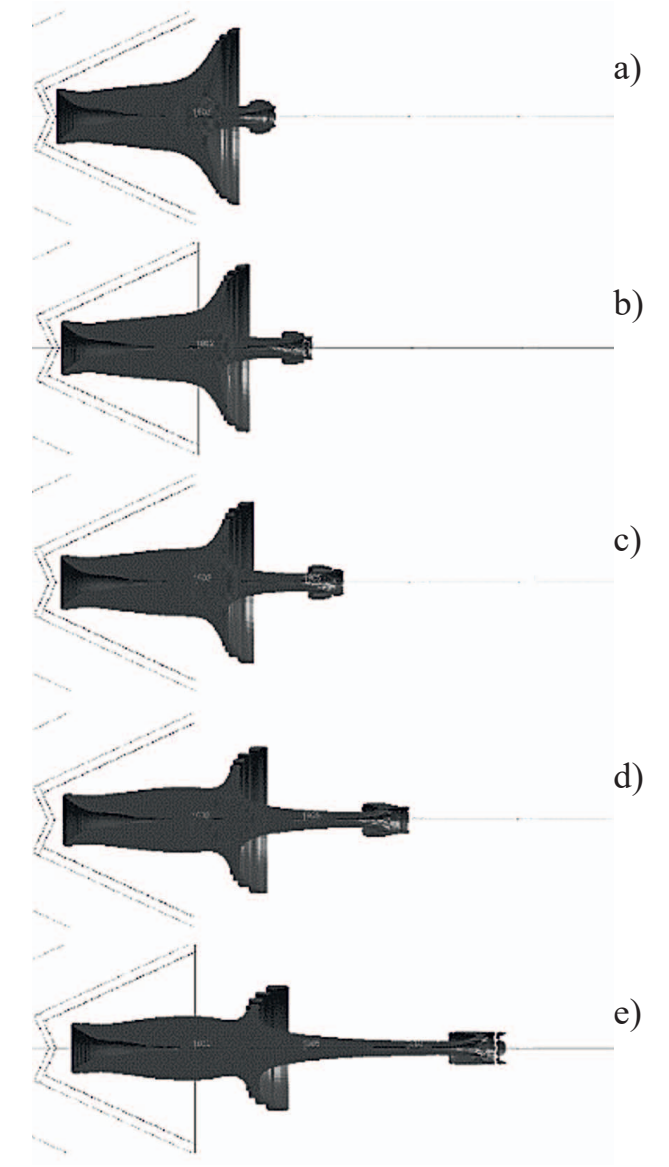

Rys. 7. Proces formowania się strumienia kumulacyjnego w hybrydowym ładunku kumulacyjnym z wkładką dzieloną dwuczęściową I po czasie: a) $12 \mu \mathrm{s}$, b) $13 \mu \mathrm{s}$, c) $14 \mu \mathrm{s}$, d) $16 \mu \mathrm{s}$, e) $19 \mu \mathrm{s}$

Fig. 7. The process of formation of the cumulative jet in a hybrid shaped charge with a two-part split liner I after the following period of time: a) $12 \mu \mathrm{s}$, b) $13 \mu \mathrm{s}$, c) $14 \mu \mathrm{s}$, d) $16 \mu \mathrm{s}$, e) $19 \mu \mathrm{s}$

Na sekwencji rysunków 7a-e przedstawiono proces formowania się strumienia kumulacyjnego. Od samego początku powstawania strumienia widoczne jest wyraźne zgrubienie w jego części czołowej. Podobnie jest w przypadku pozostałych modeli: ładunku kumulacyjnego z wkładką dzieloną dwuczęściową I oraz soczewką i ładunku kumulacyjnego z wkładką dzieloną dwuczęściową II. Zgrubienie to będzie wpływało na zwiększenie średnicy kanału perforacyjnego.

\section{Podsumowanie}

W pracy wykonano szereg analiz numerycznych polegających na zamodelowaniu różnych wariantów osiowo-kierunkowych ładunków kumulacyjnych, których konstrukcja przyczynia się do zwiększenia parametrów użytkowych. Na podstawie modelowania uzyskano kluczowe parametry i wielkości charakteryzujące zdolność do perforacji strugą kumulacyjną, takie jak: (a) prędkość ustabilizowanego strumienia kumulacyjnego (mierzoną na odcinku $52 \mathrm{~mm}$ od podstawy ładunku kumulacyjnego), (b) ciśnienie maksymalne strugi kumulacyjnej, (c) energia kinetyczna wkładki kumulacyjnej. Zamodelowano trzy warianty ładunków kumulacyjnych z wkładkami hybrydowymi: ładunek kumulacyjny z wkładką dzieloną dwuczęściową I, ładunek kumulacyjny z wkładką dzieloną dwuczęściową I oraz soczewką i ładunek kumulacyjny z wkładką dzieloną dwuczęściową II - oraz porównano je z klasycznym ładunkiem z wkładką miedzianą w kształcie stożka. Na podstawie uzyskanych parametrów analiz określono, że wszystkie nowo opracowane ładunki charakteryzują się nieco mniejszą prędkością strumienia kumulacyjnego, ale posiadają podwyższone pozostałe parametry, które wpływają na penetrację celu, przez co ładunki hybrydowe powinny skuteczniej przebijać cele (głębić kanał perforacyjny). Porównano również długości strumieni kumulacyjnych po czasie $22 \mu \mathrm{s}$. Wszystkie porównywane strumienie miały zbliżoną długość. Ładunki hybrydowe dodatkowo posiadały zgrubienie w czole strumienia, które powstaje od samego początku jego formowania. Zgrubienie to będzie zwiększało średnicę penetrowanych celów. Aby określić właściwości penetrujące cele, które bezpośrednio przekładają się na powstawanie kanałów perforacyjnych o większej objętości, powodując lepsze połączenie hydrauliczne pomiędzy złożem węglowodorów a kolumną rur okładzinowych, należałoby wykonać fizyczne modele ładunków kumulacyjnych z wkładkami hybrydowymi i sprawdzić je w warunkach poligonu doświadczalnego.

Artykuł powstał na podstawie pracy statutowej pt. Liniowy tadunek kumulacyjny do perfoszczelinowania odwiertów - praca INiG - PIB na zlecenie MNiSW; nr zlecenia: 0019/ST/2020, nr archiwalny: DK-4100-0007/2020.

\section{Literatura}

Balonek K., Gozdur S., 1999. Wprowadzenie do Metody Elementu Skończonego. Wydział Fizyki i Informatyki Stosowanej, AGH, Kraków.

Banaś K., 2020. Wprowadzenie do MES. <http://www.metal.agh.edu. pl/ banas/wprowadzenie_do_MES.pdf $>$ (dostęp: 05.03.2021).

Cheng X., Huang G., Liu Ch., Feng S., 2018. Design of a Novel Linear Shaped Charge and Factors Influencing its Penetration Performance. Applied Sciences, 8(10): 1863. DOI:_10.3390/ app8101863. 
Elbeih A., Elshenawy T., Zeman S., Akstein Z., 2018. Application of BCHMX in Shaped Charges against RHA Targets Compared to Different Nitramine Explosives. Central European Journal of Energetic Materials, 15(1): 3-17. DOI: 10.22211/cejem/81604.

Frodyma A., Koślik P., 2016. Analiza numeryczna ładunków kumulacyjnych do inicjowania propelantów modyfikowanych. Nafta-Gaz, 10: 841-850. DOI: 10.18668/NG.2016.10.09.

Hebda K., Habera L., 2020. Numerical modelling of shaped charges with an elliptical liner. Nafta-Gaz, 12: 929-933. DOI: 10.18668/ NG.2020.12.06 .

IPO, Instytut Przemysłu Organicznego, Oddział w Krupskim Młynie (2020). Karty charakterystyk ładunków kumulacyjnych osiowo-kierunkowych.

Schlumberger (1993). Schlumberger Perforating Services. Houston, Texas.

Wojewódka A., Bełzowski J., Witkowski T., 2010. Ładunki kumulacyjne i modelowanie numeryczne ich wybuchu. Chemik, 64(1): 25-32.

Zygmunt B., Wilk Z., Koślik P., 2014. Koncepcja technologii spiekanych wkładek metalicznych do ładunków EFP. Problemy Mechatroniki. Uzbrojenie, Lotnictwo, Inżynieria Bezpieczeństwa, 5(2): 63-76.

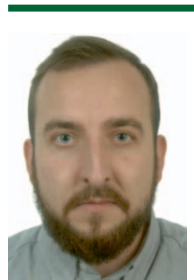

Mgr inż. Kamil Hebda

Asystent w Zakładzie Techniki Strzelniczej

Instytut Nafty i Gazu - Państwowy Instytut Badawczy

ul. Lubicz 25 A

31-503 Kraków

E-mail:kamil.hebda@inig.pl

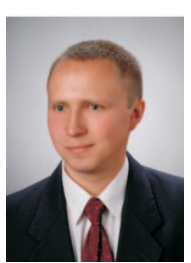

Dr inż. Łukasz HABERA

Adiunkt w Zakładzie Techniki Strzelniczej

Instytut Nafty i Gazu - Państwowy Instytut Badawczy

ul. Lubicz 25 A

31-503 Kraków

E-mail: lukasz.habera@inig.pl

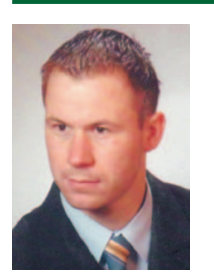

Mgr inż. Piotr KOŚLIK

Specjalista badawczo-techniczny

Sieć Badawcza Łukasiewicz - Instytut Przemysłu

Organicznego, Oddział w Krupskim Młynie

ul. Zawadzkiego 1

42-693 Krupski Młyn

E-mail: piotr.koslik@ipo.waw.pl

\section{OFERTA BADAWCZA ZAKŁADU}

\section{INŻYNIERII STRZELNICZEJ I ŚRODOWISKOWEJ}

- konstruowanie urządzeń strzelniczych przeznaczonych do udostępniania poziomów ropo- i gazonośnych;

- opracowywanie technologii i metod prowadzenia prac strzatowych w odwiertach;

- projektowanie i realizacja zabiegów intensyfikacji przyptywu medium do odwiertu poprzez szczelinowanie gazowe strefy przyotworowej ztoża prochowymi generatorami ciśnienia lub intensywne udostępnianie perfogeneratorami;

- testowanie urządzeń strzałowych w warunkach otworopodobnych na poligonie doświadczalnym;

- projektowanie, modelowanie i testy sprawnościowe tadunków kumulacyjnych;

- opracowanie raportów o oddziatywaniu na środowisko a także prognoz dotyczących emisji i rozprzestrzeniania się hatasu oraz zanieczyszczeń gazowych i pytowych do powietrza z instalacji przemystowych;

- $\quad$ pomiary emisji hałasu związanego z funkcjonowaniem instalacji przemystowych;

- monitoring powietrza glebowego w rejonach instalacji przemystowych oraz na terenach ztóż węglowodorów;

- $\quad$ prognozowanie produktywności gazowej składowisk odpadów komunalnych i ich weryfikacja poprzez testy aktywnego odgazowania;

- opracowanie koncepcji technologicznych instalacji do odgazowania składowisk i utylizacji biogazu.

Kierownik: mgr inż. Antoni Frodyma Adres: ul. Bagrowa 1, 30-733 Kraków Telefon: 126177473 Faks: 126531665 E-mail: antoni.frodyma@inig.pl

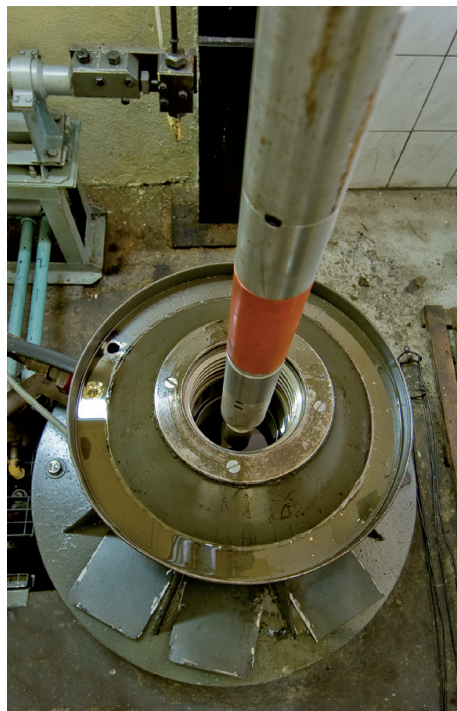

INSTYTUT NAFTY I GAZU

-Państwowy Instytut Badawczy 